\title{
Gastrointestinal helminths of two populations of wild pigeons (Columba livia) in Brazil
}

\author{
Helmintos gastrointestinais de duas populaçóes de pombos de vida livre (Columba livia) no Brasil \\ Frederico Fontanelli Vaz ${ }^{1}$; Lidiane Aparecida Firmino da Silva ${ }^{2}$; Vivian Lindmayer Ferreira ${ }^{1}$; \\ Reinaldo José da Silva²; Tânia Freitas Raso ${ }^{1 *}$ \\ ${ }^{1}$ Departamento de Patologia Veterinária, Faculdade de Medicina Veterinária e Zootecnia, Universidade de Sáo Paulo - USP, \\ Sáo Paulo, SP, Brasil \\ ${ }^{2}$ Departamento de Parasitologia, Instituto de Biociências, Universidade Estadual Paulista - UNESP, Botucatu, SP, Brasil
}

Received July 2, 2017

Accepted November 8, 2017

\begin{abstract}
The present study analyzed gastrointestinal helminth communities in 265 wild pigeons (Columba livia) living in the municipalities of São Paulo and Tatuí, state of São Paulo, Brazil, over a one-year period. The birds were caught next to grain storage warehouses and were necropsied. A total of 790 parasites comprising one nematode species and one cestode genus were recovered from 110 pigeons, thus yielding an overall prevalence of $41.5 \%$, mean intensity of infection of $7.2 \pm 1.6$ (range 1-144) and discrepancy index of 0.855 . Only 15 pigeons (5.7\%) presented mixed infection. The helminths isolated from the birds were Ascaridia columbae (Ascaridiidae) and Raillietina sp. (Davaineidae). The birds' weights differed according to sex but this did not influence the intensity of infection. The overall prevalence and intensity of infection did not differ between the sexes, but the prevalence was higher among the birds from Tatuí $(47.8 \%)$. The gastrointestinal helminth community of C. livia was characterized in the two areas studied and parasite homogeneity was observed over the 12 months analyzed at both locations. These results make contributions to the current literature on health aspects of wild C. livia populations.
\end{abstract}

Keywords: Columbiformes, helminthology, nematodes, cestodes, Ascaridia, Raillietina.

\section{Resumo}

O presente estudo analisou comunidades gastrointestinais de helmintos em 265 indivíduos de Columba livia de vida livre nos municípios de São Paulo e Tatuí, estado de São Paulo, Brasil, durante um ano. As aves foram capturadas em áreas de armazenamento de grãos e sementes e necropsiadas. Um total de 790 parasitos representando uma espécie de nematódeo e um gênero de cestoide foram recuperados de 110 pombos com uma prevalência geral de $41,5 \%$, intensidade média de infecção de 7,2 \pm 1,6 (amplitude 1-144) e índice de discrepância de 0,855. Somente 15 (5,7\%) pombos tiveram uma infecção mista. Os helmintos isolados das aves foram Ascaridia columbae (Ascaridiidae) e Raillietina sp. (Davaineidae). O peso das aves foi diferente entre os sexos, mas não influenciou a intensidade de infecção. A prevalência geral e a intensidade de infecção não foram diferentes entre sexo, mas a prevalência foi maior nas aves de Tatuí (47,8\%). A comunidade gastrointestinal de helmintos de C. livia foi caracterizada nas duas áreas estudadas e uma homogeneidade de parasitos foi observada nos 12 meses analisados, em ambas localidades. Os resultados contribuem para a literatura atual sobre aspectos sanitários de populaçóes de $C$. livia em vida livre.

Palavras-chave: Columbiformes, helmintologia, nematódeos, cestódeos, Ascaridia, Raillietina.

*Corresponding author: Tânia Freitas Raso. Departamento de Patologia Veterinária, Faculdade de Medicina Veterinária e Zootecnia, Universidade de São Paulo - USP, Av. Prof. Dr. Orlando Marques de Paiva, no 87, Cidade Universitária, CEP 05508-270, São Paulo, SP, Brazil. e-mail: tfraso@usp.br 


\section{Introduction}

Pigeons (Columba livia) belong to the order Columbiformes and have adapted to adverse conditions in different parts of the world. They are often present at high densities in urban areas such as public parks and live very close to humans and domestic/wild animal species (HARLIN, 1994). These close interactions can be of concern, since pigeons might serve as a potential reservoir of parasites, with the capacity to spread them to wild birds, including threatened species (FORONDA et al., 2004; RADFAR et al., 2012).

Studies around the world have identified the parasitic communities that occur in pigeons and have recognized that gastrointestinal helminths are very common in this species, which can harbor these parasites without showing evident clinical signs (TORO et al., 1999). Nonspecific helminths infecting C. livia have been reported (FORONDA et al., 2004) and can vary according to the season, sex, and locations (SENLIK et al., 2005; SMITH \& FEDYNICH, 2012). Despite this, little attention has been given to this avian species in Brazil, where its numbers have been increasing. Moreover, few data about health issues relating to wild pigeons are available in the veterinary medical literature (PEREZ, 2005; FERREIRA et al., 2016).

More information about the health of wild pigeons is essential, considering the overpopulation problems relating to this non-native species in Brazil. Therefore, the aims of this study were to identify the gastrointestinal helminths of two C. livia populations in the state of São Paulo, to assess any differences between the sexes and locations and to evaluate the effect of weight on the intensity of infection in these birds.

\section{Materials and Methods}

\section{Study areas and collection of pigeons}

This study was carried out at two grain storage warehouse facilities that had been suffering from an overpopulation of pigeons. The warehouses are located in the municipalities of São Paulo and Tatuí, state of São Paulo, Brazil, representing an urban area and a rural area, respectively, 87 miles from each other. Pigeons were caught randomly using traps in the same place at each locality once a month over a one-year period (January to December).

The birds were manually restrained, weighed and euthanized with approval from the Bioethics Commission of the School of Veterinary Medicine and Animal Science of the University of São Paulo (under number 1605) and authorization from ICMBio/SISBIO (Chico Mendes Institute for Biodiversity Conservation, under number 18919-1).

\section{Parasitological analysis}

The pigeons were necropsied and the gastrointestinal tracts were removed and surveyed for parasites under a stereomicroscope. Any nematodes that were found were preserved in $70 \%$ ethanol, cleared with lactophenol and identified based on Vicente et al. (1995). Cestodes were fixed in AFA solution under slight pressure from a coverslip, stained with hydrochloric acid-carmine and identified in accordance with Schmidt (1986). The parasites were analyzed using the Qwin Lite 2.5 computerized system (Leica Microsystems, Wetzlar, Germany).

\section{Statistical analysis}

The prevalence with $95 \%$ confidence interval $(\mathrm{CI})$ and mean intensity of infection (MII) with 95\% CI were calculated as described by Bush et al. (1997), using the Quantitative Parasitology 3.0 software. Differences in weight between the sexes and differences in MII between the sexes and locations were determined using the Mann-Whitney test. The effect of weight on the intensity of infection was determined using Spearman's correlation test for each sex. The chi-square test was performed to analyze the influence of sex and location on the prevalence of the parasites. These tests were calculated using the BioEstat 5.3 software and the significance level used was $5 \%$. A discrepancy index (D) was calculated as described by Poulin (1993), using the Quantitative Parasitology 3.0 software (RÓZSA et al., 2000).

\section{Results}

A total of 265 specimens of $C$. livia were caught during the study period, comprising 146 females (55.1\%) and 119 males (44.9\%), with an average of 11 pigeons per month at each location. The birds had an overall mean weight of $258.7 \mathrm{~g}$ (range 140-360 g). The mean weight of the males $(268.5 \mathrm{~g})$ was greater than that of the females $(250.7 \mathrm{~g})(\mathrm{U}=6325.50 ; p=0.0001)$. Weight had no effect on the intensity of infection, either for males ( $\mathrm{rs}=0.1552 ; p=0.090$ ) or for females ( $r s=0.1528 ; p=0.0087$ ).

A total of 790 parasites, consisting of Ascaridia columbae (Ascaridiidae) and Raillietina sp. (Davaineidae), were recovered from 110 specimens of $C$. livia (overall prevalence $=41.5 \%$ ). Fifteen pigeons (5.7\%; nine females and six males) presented mixed infection. The overall prevalence (P), MII and discrepancy index (D) are showed in Table 1, which also shows these data per parasite and per municipality. Both helminth species presented a tendency towards aggregated distribution $(D=0.855)$ among the pigeons.

Most of the birds had five or fewer parasites in the intestine: $76.1 \%(35 / 46)$ in the municipality of São Paulo and 71.9\% (46/64) in the municipality of Tatuí. Five pigeons (10.9\%) in São Paulo and nine (14.1\%) in Tatuí had 6-10 parasites; and four (8.7\%) and $8(12.5 \%)$ in these cities had $11-50$ parasites, respectively. Just two birds in São Paulo (4.3\%) and one (1.8\%) in Tatuí had more than 50 parasites.

The overall prevalence and MII did not differ between the sexes, but the prevalence was higher among the birds from the municipality of Tatuí (Table 2).

\section{Discussion}

The evaluation of two populations of wild C. livia in the states of São Paulo and Minas Gerais determined the prevalence of helminths in the gastrointestinal tract, showing 
Table 1. Gastrointestinal helminths of two wild pigeon populations (Columba livia) in the municipalities São Paulo and Tatuí, state of São Paulo, Brazil.

\begin{tabular}{|c|c|c|c|c|c|c|}
\hline Helminth species & $\begin{array}{l}\text { Reservoir } \\
\text { location }\end{array}$ & Host $(\mathrm{N})$ & P (95\% CI) (\%) & MII (95\% CI) (range) & $D$ & Site \\
\hline \multicolumn{7}{|l|}{ Ascaridiidae } \\
\hline \multirow[t]{2}{*}{ Ascaridia columbae } & SP & 131 & $16.0(10.2-23.5)$ & $\begin{array}{c}15.4(6.0-38.8) \\
(1-144)\end{array}$ & 0.956 & Intestine \\
\hline & TA & 134 & $34.3(26.3-43.0)$ & $\begin{array}{c}6.2(4.1-10.7) \\
(1-62)\end{array}$ & 0.856 & \\
\hline \multicolumn{7}{|l|}{ Davaineidae } \\
\hline \multirow[t]{2}{*}{ Raillietina sp. } & SP & 131 & $23.7(16.7-31.9)$ & $\begin{array}{c}3.3(2.4-5.1) \\
(1-18)\end{array}$ & 0.857 & Intestine \\
\hline & TA & 134 & $20.2(13.7-27.9)$ & $\begin{array}{c}2.9(2.1-4.7) \\
(1-15)\end{array}$ & 0.886 & \\
\hline Total & $\mathrm{SP}+\mathrm{TA}$ & 265 & $41.5(35.5-47.7)^{*}$ & $\begin{array}{c}7.2(5.0-11.8) \\
(1-144)\end{array}$ & 0.855 & \\
\hline
\end{tabular}

${ }^{*}$ Based on the fact that 15 birds had both parasites ( 155 birds were not parasitized). $\mathrm{N}=$ number of pigeons examined; $\mathrm{P}=$ prevalence; $\mathrm{CI}=$ confidence interval; MII = mean intensity of infection; $D=$ aggregation index; SP = São Paulo; TA = Tatuí.

Table 2. Comparison of prevalences and mean intensity of infection of gastrointestinal helminths in 265 wild pigeons (Columba livia) from the state of São Paulo, Brazil.

\begin{tabular}{ccccc}
\hline & Prevalence (\%) & Test (p) & MII & Test (p) \\
\hline Municipality of São Paulo & 35.1 & $\chi^{2}=4.364(0.0367)$ & 9 & $\mathrm{U}=1424.5(0.7735)$ \\
Municipality of Tatuí & 47.8 & & 6 & $\mathrm{U}$ \\
Males & 47.0 & $\chi^{2}=1.888(0.1694)$ & 6 & $\mathrm{U}=1941(0.9645)$ \\
Females & 39.0 & & 7 & \\
\hline
\end{tabular}

MII = mean intensity of infection.

values of $4.9-29.1 \%$ for $A$. columbae and 14.6-24.6\% for Raillietina sp. (OLIVEIRA et al., 2000; PEREZ, 2005). Some of these findings were similar to those of the present study. However, the prevalence of $A$. columbae and Raillietina sp. in wild $C$. livia vary widely between different locations, ranging from 5.0 to $46.7 \%$ and from 1.7 to $100.0 \%$, respectively (TORO et al., 1999; FORONDA et al., 2004; BEGUM \& SEHRIN, 2012; EDOSOMWAN et al., 2012; DIAKOU et al., 2013; DIPINETO et al., 2013). The MII (9.1) and range of parasitism (1-144) for $A$. columbae in the present study were similar to those in previous reports: mean intensities of 8.4 and 8.5 and ranges of 1-107 parasites (FORONDA et al., 2004; SENLIK et al., 2005), but lower MII (3.2) was observed among 55 semi-captive C. livia in the state of Rio de Janeiro (SILVA et al., 1990). Differently, a mean value of 12.3 was reported for Raillietina sp. among 50 wild C. livia in Spain (FORONDA et al., 2004), which was higher than the MII of the present study (3.2). Concerning mixed infections, similar prevalence in the state of Minas Gerais (3.3\%) and higher prevalence in the state of São Paulo (14.6\%) was observed in previous studies on wild pigeons. Nevertheless, both of these studies showed higher single infection than mixed infection (OLIVEIRA et al., 2000; PEREZ, 2005), which is in agreement with the present study.

Discrepant results can be found between helminth surveys because all the parasitological values included in the present study vary widely according to extrinsic environmental factors such as geographic location, season and precipitation, and to intrinsic factors such as diet, immunity, co-occurring diseases, host susceptibility behavior, age and sex (FEDYNICH, 2008). Three pigeons in our study presented discrepant numbers of parasites $(>50)$ that did not correspond to normal values, thus reinforcing the influence of intrinsic factors on values within the same investigation.

Low diversity of gastrointestinal helminths was observed in the present study. The species found in these pigeons are very common (Table 3). In the past, some authors found a similar diversity of parasite species (2-3 species) in wild and captive pigeons in the states of São Paulo and Minas Gerais (GIOVANNONI \& MALHEIRO, 1952; FEDERMAN et al., 1973; OLIVEIRA et al., 2000). Other studies in Brazil and other countries have reported three to five helminth species in wild and semi-captive pigeons using diagnostic methods similar to those of the present study (CARNEIRO et al., 1975; SILVA et al., 1990; FORONDA et al., 2004; PEREZ, 2005; SMITH \& FEDYNICH, 2012). Unfortunately, it was not possible to differentiate the species of Raillietina, which might have increased the number of helminth species in the present study. However, the low diversity of gastrointestinal helminths observed may have been a reflection of the local environment where the pigeons were feeding (SMITH \& FEDYNICH, 2012). They had probably concentrated their feeding at the grain storage warehouse facilities and had acquired fidelity to these locations because these provided shelter, nest sites and, especially, a large variety of grains in large amounts. This fidelity to the warehouses probably decreased their exposure to the direct life cycle of nematodes and to intermediate hosts, which might be experienced by other 
Table 3. Species of gastrointestinal helminths found in Columba livia in Brazil.

\begin{tabular}{|c|c|c|c|c|c|}
\hline Parasite family & Parasite species & Bird origin & $\mathbf{N}$ & Prevalence (\%) & Reference \\
\hline \multirow{7}{*}{ Ascaridiidae } & Ascaridia columbae & Wild (SP) & 265 & 25.3 & This study \\
\hline & & Wild (SP) & 199 & 29.1 & Perez (2005) \\
\hline & & Wild (MG) & 61 & 4.9 & Oliveira et al. (2000) \\
\hline & & Semi-captive (RJ) & 55 & 11.4 & Silva et al. (1990) \\
\hline & & Not stated (GO) & 30 & 65.5 & Carneiro et al. (1975) \\
\hline & & Captive (MG) & 11 & 45.0 & Federman et al. (1973) \\
\hline & & Captive (SP) & 100 & 57.0 & Giovannoni \& Malheiro (1952) \\
\hline \multirow[t]{5}{*}{ Trichuridae } & Capillaria columbae & Wild (SP) & 199 & 6.5 & Perez (2005) \\
\hline & & Semi-captive (RJ) & 55 & 25.7 & Silva et al. (1990) \\
\hline & & Not stated (GO) & 30 & 8.3 & Carneiro et al. (1975) \\
\hline & & Captive (MG) & 11 & 18.2 & Federman et al. (1973) \\
\hline & & Captive (SP) & 100 & 4.0 & Giovannoni \& Malheiro (1952) \\
\hline Acuariidae & Dispharynx spiralis & Semi-captive (RJ) & 55 & 2.8 & Silva et al. (1990) \\
\hline \multirow[t]{2}{*}{ Tetrameridae } & Tetrameres confusa & Captive (SP) & 100 & 1.0 & Giovannoni \& Malheiro (1952) \\
\hline & & Not stated (GO) & 30 & 4.1 & Carneiro et al. (1975) \\
\hline \multirow[t]{6}{*}{ Davaineidae } & Raillietina sp. & Wild (SP) & 265 & 21.9 & This study \\
\hline & & Wild (MG) & 61 & 24.6 & Oliveira et al. (2000) \\
\hline & & Not stated (GO) & 30 & 4.1 & Carneiro et al. (1975) \\
\hline & Raillietina (Raillietina) allomyodes & Wild (SP) & 199 & 14.6 & Perez (2005) \\
\hline & Raillietina (Fuhrmannetta) crassula & Wild (SP) & 199 & 19.1 & Perez (2005) \\
\hline & Raillietina (Skrjabinia) bonini & Semi-captive (RJ) & 55 & 45.7 & Silva et al. (1990) \\
\hline \multirow[t]{2}{*}{ Brachylaemidae } & Brachylaemus (Mazzantia) mazzantii & Wild (SP) & 199 & 3.0 & Perez (2005) \\
\hline & & Semi-captive (RJ) & 55 & 25.7 & Silva et al. (1990) \\
\hline
\end{tabular}

$\mathrm{N}$ = number of birds examined; $\mathrm{SP}=$ São Paulo; $\mathrm{MG}$ = Minas Gerais; $\mathrm{RJ}$ = Rio de Janeiro; $\mathrm{GO}$ = Goiás.

pigeons foraging in environments with greater diversity or at natural feeding sites (SMITH \& FEDYNICH, 2012).

Furthermore, the prevalence of helminths found in C. livia from Tatuí was higher than that found in pigeons from São Paulo (Table 2). This result was probably due to the influence of the local environment. The warehouse in Sáo Paulo is located in an urban area, while the warehouse in Tatuí is located in a rural area, which gives the pigeons wider possibilities for foraging at natural sites and maybe more exposure to helminths and intermediate hosts (SMITH \& FEDYNICH, 2012). Moreover, in rural areas, the pigeons may have more contact with other avian species.

Similar numbers of males and females were caught in the present study, given that males and females live in close association, such that they move and feed together. Thus, the rate of parasitism would be expected to be similar in the two sexes because of equal exposure to parasites, as reported in other studies (TORO et al., 1999; FORONDA et al., 2004; SENLIK et al., 2005).

Ascaridia columbae is widely distributed and has been found not only in many dove species but also in other avian orders such as Psittaciformes (FEDYNICH, 2008). The genus Raillietina has a cosmopolitan distribution and is of major clinical importance for poultry. Some nonspecific species of this genus have the potential to be transmitted to other wild avian species (DIAKOU et al., 2013). Therefore, the pigeons investigated in this study may be important transmitters of helminths to other wild/domestic bird species. However, further studies are needed in order to understand the possible impacts of these populations and to establish management and control measures. Similarly, further studies are needed in order to correlate ecological features such as reproduction characteristics, food intake, use of microhabitat and time of activity between the sexes, so as to better understand the influences of sex on MII and prevalence of helminths.

Although the overpopulation of pigeons presents some risks around the world, little is known about their health, and the findings from the present study make several contributions to the current literature. The gastrointestinal helminth community of a significant number of specimens of wild C. livia was reported, and such data are scarce in Brazil, particularly regarding free-living birds. Parasite homogeneity was observed over the 12 months analyzed at both locations in the present study, which provided a longitudinal evaluation on the helminth fauna in wild pigeons in Brazil.

\section{References}

Begum A, Sehrin S. Gastrointestinal helminths in pigeon Columba livia (Gmelin, 1789). J Asiat Soc Bangladesh 2012; 38(1): 93-98.

Bush AO, Lafferty KD, Lotz JM, Shostak AW. Parasitology meets ecology on its own terms: Margolis et al. revisited. J Parasitol 1997; 83(4): 575583. PMid:9267395. http://dx.doi.org/10.2307/3284227.

Carneiro JR, Lustosa ES, Pereira E, Carvalho ED, Napoli MA. Incidência de ecto e endoparasitos de pombos (Columba livia domestica) em Goiânia. Rev Patol Trop 1975; 4(1): 39-41. 
Diakou A, Ptochos S, Papadopoulos E. Cestode fauna of feral pigeons in Thessaloniki; Northern Greece. Helminthologia 2013; 50(1): 39-42. http://dx.doi.org/10.2478/s11687-013-0105-7.

Dipineto L, Borrelli L, Pepe P, Fioretti A, Caputo V, Cringoli G, et al. Synanthropic birds and parasites. Avian Dis 2013; 57(4): 756-758. PMid:24597118. http://dx.doi.org/10.1637/10602-062713-Reg.1.

Edosomwan EU, Gabaolu C, Enabulele EE. Ecto and gastrointestinal parasites of captured wild pigeons in Benin city, Nigeria. Nigerian J Parasitol 2012; 33(1): 27-30.

Federman HB, Holanda JC, Evangelista A. Ocorrência de parasitos em gatos (Felis catus domesticus) e pombos (Columba livia) procedentes de algumas localidades de Minas Gerais. Rev Patol Trop 1973; 2(2): 207-215.

Fedynich AM. Heterakis and Ascaridia. In: Atkinson CT, Thomas NJ, Hunter DB , editors. Parasitic diseases of wild birds. Iowa: Wiley-Blackwell; 2008. p. 388-412.

Ferreira VL, Dias HA, Raso TF. Screening of feral pigeons (Columba livia) for pathogens of veterinary and medical importance. BrazJ Poultry Sci 2016; 18(4): 701-704.

Foronda P, Valladares B, Rivera-Medina JA, Figueruelo E, Abreu N, Casanova JC. Parasites of Columba livia (Aves: Columbiformes) in Tenerife (Canary Islands) and their role in the conservation biology of the laurel pigeons. Parasite 2004; 11(3): 311-316. PMid:15490756. http://dx.doi. org/10.1051/parasite/2004113311.

Giovannoni M, Malheiro DM. Incidência de parasitas em Columba livia domestica. Rev Fac Med Vet 1952; 4(4): 595-598. http://dx.doi. org/10.11606/issn.2318-5066.v4i4p595-598.

Harlin RW. Pigeons. Vet Clin N Am - Small 1994; 24(1): 157-173.

Oliveira PR, Mundin MJS, Cabral DD, Ribeiro SCA, Rosa GN. Levantamento da fauna parasitária das pombas domésticas (Columba livia) de Uberlândia, MG, Brasil. Vet Not 2000; 6(2): 53-56.

Perez RR. Helmintofauna de Columba livia (Aves, Columbidae) procedentes do estado de São Paulo [dissertação]. Botucatu: Universidade Estadual Paulista; 2005.
Poulin R. The disparity between observed and uniform distributions: a new look at parasite aggregation. Int J Parasitol 1993; 23(7): 937-944. PMid:8106186. http://dx.doi.org/10.1016/0020-7519(93)90060-C.

Radfar MH, Asl EN, Seghinsara HR, Dehaghi MM, Fathi S. Biodiversity and prevalence of parasites of domestic pigeons (Columba livia domestica) in a selected semiarid zone of South Khorasan, Iran. Trop Anim Health Prod 2012; 44(2): 225-229. PMid:22081317. http://dx.doi.org/10.1007/ s11250-011-0002-3.

Rózsa L, Reiczigel J, Majoros G. Quantifying parasites in samples of hosts. J Parasitol 2000; 86(2): 228-232. PMid:10780537. http://dx.doi. org/10.1645/0022-3395(2000)086[0228:QPISOH]2.0.CO;2.

Schmidt GD. CRC Handbook of tapeworm identification. Florida: CRC Press; 1986.

Senlik B, Gulegen E, Akyol V. Effect of age, sex and season on the prevalence and intensity of helminth infections in domestic pigeons (Columba livia) from Bursa Province, Turkey. Acta Vet Hung 2005; 53(4): 449-456. PMid:16363146. http://dx.doi.org/10.1556/AVet.53.2005.4.5.

Silva CC, Mattos DG Jr, Ramires PM. Helmintos parasitas de Columba livia $(\mathrm{Gm})$ no município de São Gonçalo, Rio de Janeiro. Arq Bras Med Vet Zootec 1990; 42(5): 391-394.

Smith AJ, Fedynich AM. Helminth community composition, structure, and pattern in six dove species (Columbiformes: Columbidae) of south Texas. J Parasitol 2012; 98(1): 11-21. PMid:21955248. http://dx.doi. org/10.1645/GE-2561.1.

Toro H, Saucedo C, Borie C, Gough RE, Alcaino H. Health status of free-living pigeons in the City of Santiago. Avian Pathol 1999; 28(6): 619-623. http://dx.doi.org/10.1080/03079459994416.

Vicente JJ, Rodrigues HO, Gomes DC, Pinto RM. Nematódeos do Brasil. Parte IV: Nematóides de aves. Rev Bras Zool 1995;12(1 suppl 1): 1-273. http://dx.doi.org/10.1590/S0101-81751995000500001. 